\title{
Synthesis and Characterization of Composite Material Based on Modified Phenolic Resin
}

\author{
Mahendrasinh $\mathbf{R a j}^{1}{ }^{1, *}$, Lata $\mathbf{R a j}^{2}$ \\ ${ }^{1}$ Polymer Science \& Technology Department, Institute of Science \&Technology for Advanced Studies\& Research (ISTAR), \\ VallabhVidyanagar, Anand, Gujarat, India \\ ${ }^{2}$ Chemistry Department, C.N.P.F Arts and D.N Science College, Dabhoi, Vadodara, Gujarat, India
}

Email address:

drmahendramraj@gmail.com (M. Raj)

${ }^{*}$ Corresponding author

To cite this article:

Mahendrasinh Raj, Lata Raj. Synthesis and Characterization of Composite Material Based on Modified Phenolic Resin. American Journal of Applied Chemistry. Vol. 4, No. 3, 2016, pp. 84-90. doi: 10.11648/j.ajac.20160403.13

Received: April 2, 2016; Accepted: April 12, 2016; Published: May 11, 2016

\begin{abstract}
Acid and base catalyzed polycondensationreaction of phenol and bisphenol A with crotonaldehyde and cardanol results in novolac and resol type phenolic resins. Phenolic oligomers are characterized by their viscosity, average molecular weight and FT-IR spectral studies. Glass reinforced composites of all phenolic oligomers were prepared. Composites are characterized by their synergetic thermal stability by Thermo gravimetric analysis (TGA), Differential scanning calorimery (DSC), Scanning electron microscopy (SEM), and mechanical properties such as flexural strength, impact strength and hardness, chemical resistance, fibre content over a broad range of compositions. The thermal and curing behavior of the resins are found to vary markedly with the mole ratio and the purity of crotonaldehyde or cardanol. Composites prepared from these resin having very good mechanical properties.
\end{abstract}

Keywords: Novolac, Resol, Phenolic Oligomer, Mechanical Properties, SEM

\section{Introduction}

The development of new and improved polymers and their application innovel areas have led to innumerable new products. Polymers differ in characteristics because of their unique structural complexities. Polymers are classified as plastics, thermoplastics elastomer and fibers, the properties of individual members of the same group vary widely. A change in the nature of pendant groups, arrangement of the monomer units or change in the reaction conditions, catalysts etc. can tremendously change the properties of individual polymers. For the last five decades researchers have been extensively exploring all possibilities to discover novel polymers [1-7]. This has been achieved by blending different types of polymers together so that the properties of one polymer offset the drawbacks of the other or by othertechniques like addition of filler or reinforcements [8$11]$.

Thermosetting plastics [12], can be cured and converted into a permanent shape. Curing of thermosetting resin is an irreversible chemical reaction occurs under the influence of heat and/or catalyst and leads to a three dimensional chemical structures. For some thermosetting materials, curing is initiated or completed even at room temperature. Although the cured part can be softened by heat, it cannot be remolded or restored to the flow able state that existed before curing and continued heating for longer time leads to degradation or decomposition.

The resin properties can be modified by reacting phenol with other aldehydes, by etherification of phenol, and by using substituted phenols. The present investigation focused on modifying a phenolic resin by the partial substitution of phenol with cardanol in the synthesis with formaldehyde. The purpose of these modifications was to prepare a flexible polymer with rubberlike elasticity. Cashew nut shell liquid (CNSL) is a natural product obtained from the shells of the cashew nut. The Cashew nut has a shell of about $1 / 8$ inch thickness, with a soft honeycomb structure 
inside, containing a dark brown viscous liquid. It is called cashew nut shell liquid (CNSL), which is pericarp fluid of the cashew nut. [13] CNSL is extraction from cashew nut shell (CNS) by using of different methods. The heating process (roasting) can be achieved by open recipients or drums. [14] The cashews can also be heated by CNSL in a process denominated as thermo - mechanic (hot oil process). [15] In the cold, the CNSL can be obtained by extrusion, in solvents or by pressing. The cashew's liquid obtained by the cold is denominated as natural CNSL and when extracted in hot is denominated technical CNSL. In its natural form, crude CNSL is a mixture of different phenolic compounds. The main constituent is cardanol and also there are present anacrdic acid and cardol. Because of the phenolic nature and unsaturation in the side chain, cardanol offers reaction sites on the aromatic ring and also on the side chain, which makes it a suitable raw material for variety of reactions. Cardanol reacts with active methylenes like formaldehyde or hexamethylenetetramine via the hydroxyl group and can undergo addition polymerization through unsaturation present in the side chain. Therefore, different type of resins can be synthesized from cardanol, and also from chemically modified CNSL $[16,17]$.

\section{Experimental}

\subsection{Materials}

All the chemicals used were of laboratory grade. E-type of glass -woven fabric $0.25 \mathrm{~mm}$ thick was used for composite fabrication.

\subsection{Novolac Type Resin}

\subsubsection{Syntheses of Phenol-Crotonaldehyde Resin (NPC)}

In a three neck flask, $23.75 \mathrm{gm}$ of phenol, $15.18 \mathrm{gm}$ of crotonaldehyde and 0.375 gm. oxalic acid. The liquor is warmed continuously under reflux. As soon as bubble start to rise, showing that the exothermic reaction. Heat the flask to $60-80^{\circ} \mathrm{C}$ for at least $2-3 \mathrm{~h}$. A time will reach when the bubble will escape very difficultly from the surface of the solution. At that time stop heating and pour immediately the content of flask in previously weighed container. The percent yield was obtained about $70 \%$.

\subsubsection{Syntheses of Bisphenol A-Crotonaldehyde Resin (NBC)}

In a three neck flask, 49gm of phenol, 15.18gm of crotonaldehyde and $0.375 \mathrm{gm}$. oxalic acid. The liquor is warmed continuously under reflux. As soon as bubble start to rise, showing that the exothermic reaction. Heat the flask to $60-80^{\circ} \mathrm{C}$ for at least $2-3 \mathrm{~h}$. A time will reach when the bubble will escape very difficultly from the surface of the solution. At that time stop heating and pour immediately the content of flask in previously weighed container. The percent yield was obtained about $70 \%$.

\subsection{Resol Type Resin}

\subsubsection{Syntheses of Phenol-Crotonaldehyde Resin (RPC)}

In a three neck flask, $23.75 \mathrm{gm}$ of phenol, 34gm of crotonaldehyde and $10 \%$ liq. ammonia on the basis of weight of crotonaldehyde and mixed them together. Attach reflux condenser to the flask. Reflux the content of the flask directly on heating mental. First heat slowly then strongly for $30 \mathrm{~min}$ at a temperature of $70-80^{\circ} \mathrm{C}$. After this period the mixture acquires red color and it becomes viscous on heating. A time will reach when the bubble will escape very difficultly from the surface of the solution. At that time stop heating and pour immediately the content of flask in previously weighted container. The percent yield was obtained about $75 \%$.

\subsubsection{Syntheses of Bisphenol A - Crotonaldehyde Resin ( $R B C$ )}

In a three neck flask, $49 \mathrm{gm}$ of bisphenol A, 34gm of crotonaldehyde and $10 \%$ liq. ammonia on the basis of weight of crotonaldehyde and mixed them together. Attach reflux condenser to the flask. Reflux the content of the flask directly on heating mental. First heat slowly then strongly for $30 \mathrm{~min}$ at a temperature of $70-80^{\circ} \mathrm{C}$. After this period the mixture acquires red color and it becomes viscous on heating. A time will reach when the bubble will escape very difficultly from the surface of the solution. At that time stop heating and pour immediately the content of flask in previously weighted container. The percent yield was obtained about $72 \%$.

\subsubsection{Syntheses of Cardanol - Formaldehyde Resin (RCF)}

In a three neck flask, $76.5 \mathrm{gm}$ of cardano 1,15 gm of formaldehyde and $10 \%$ liq. ammonia on the basis of weight of crotonaldehyde and mixed them together. Attach reflux condenser to the flask. Reflux the content of the flask directly on heating mental. First heat slowly then strongly for $30 \mathrm{~min}$ at a temperature of $70-80^{\circ} \mathrm{C}$. After this period the mixture acquires red color and it becomes viscous on heating. A time will reach when the bubble will escape very difficultly from the surface of the solution. At that time stop heating and pour immediately the content of flask in previously weighted container. The percent yield was obtained about $78 \%$.

\section{Characterization}

FTIR spectra of all the phenolic oligomers were recorded using Perkin Elmer Lambda-19 FTIR spectrometer employinga thin layer of the sample on a $\mathrm{KBr}$ cell. Number average molecular weight of the phenolic oligomer were measured by using vapour pressure osmometer Knaller (Germany K.7000) using DMF as solvent as per ASTM D 3592-77. The viscosities of phenolic oligomers were measured by Brookfield RVF viscometer as per ASTM D 1824.Differential Scanning Calorimtry of the selected sample was carried out by Perkin Elmer Pyris DSC instrument at $10^{\circ} \mathrm{C}$ heating rate. Scanning Electron Microscopy of selected sample is carried out by Phillips ESEM EDAX XL-30. 


\section{Composite Fabrication}

Glass reinforced composite were prepared employing hand layup prepreg formation technique. The composites were fabricated using resin to glass fabric ratio of 60:40. The resin was prepared and stirred for 5-10 minutes and the resultant mixture was applied on a glass fabric (15 X 12) with the brush and allowed to dry. Ten such dried prepregs prepared in similar way were stacked one over other and pressed between two steel plates using teflon sheet as mould releasing agent. Subsequently, these plates were pre-cured in a compression moulding machine at $75-80^{\circ} \mathrm{C}$ for 25 minutes. The pre-curing temperature was raised to $140^{\circ} \mathrm{C}$ and $150-200$ psipressure was applied for 15-20 minutes. After completion of curing the plates were cooled to $50^{\circ} \mathrm{C}$ before pressure was released. These composites were tested as per various standard methods [18]. Specimens of dimension $130 \mathrm{~mm} \mathrm{X} 12.7 \mathrm{~mm}$ were taken for measurement of flexural strength as per ASTM D 790, employing Instron testing machine. The tests were carried out at a crosshead speed of $100 \mathrm{~mm} / \mathrm{min}$ and span length of $75 \mathrm{~mm}$ respectively. Izod impact strength of un-notched samples of dimensions $65 \mathrm{~mm} X 13 \mathrm{~mm}$ was measured as per ASTM D256. Rockwell hardness of the composites was measured employing specimens of dimensions $25 \mathrm{~mm} \mathrm{X} \mathrm{25mm} \mathrm{as} \mathrm{per} \mathrm{ASTM} \mathrm{D} \mathrm{785.} \mathrm{All} \mathrm{the}$ mechanical tests were conducted at room temperature. Chemical resistance tests were carried out as per ASTM D 543. Test specimens of dimensions $76.2 \mathrm{mmX} 25.4 \mathrm{~mm}$ were tested in presence of $10 \% \mathrm{NaOH}, 10 \% \mathrm{H}_{2} \mathrm{SO}_{4}$, Dioxane, DMF and water.

\section{Results \& Discussion}

Phenolic oligomers are obtained by polycondensation reaction and characterized them by different ways. Number average molecular weights ( $\overline{M n}$ ) for all the phenolic oligomers were observed in the range of5000 - $6000 \mathrm{gm} /$ mole. The viscosity data of phenolic oligomers were found in the range of $900-1100 \mathrm{cP}$. Inspection of IR spectrum reveals that they resemble each other in general appearance. However there are noticeable differences in certain frequencies. The overall results of IR spectral studies shown in Table 1. Crotonaldehyde absorbs at frequencies corresponding to the trans $\mathrm{C}=\mathrm{C}$ double bond and $\mathrm{C}=\mathrm{O}$ groups. The resins and their fractions do not absorb at these frequencies. Therefore, the polycondensation reaction probably proceeds by addition across the $\mathrm{C}=\mathrm{C}$ double bond and condensation across the aldehyde group [19-20].

Figure 1 shows the Differential Scanning Calorimetry (DSC) thermogram for phenolic oligomers. Endothermic peaks below $140^{\circ} \mathrm{C}$ were observed, related to evaporate the adsorbed reactant in the oligomer. This results in accordance to no further chemical or physical treatment is applied in curing process. The endothermic peaks attributes to molecular motion is appeared during curing process [21].
The mechanical properties of glass reinforced composites based on phenolic oligomers prepared are represented in Table 2. The data of flexural andimpact strength values of glass reinforced composites based on phenolic oligomers showed synergistic effects. This behavior can be explained on the basis of permanent physical chain entanglements resulting due to the presence of aromatic moiety of phenol or bisphenol A and crotonaldehyde or cardanol. [22]. Rockwell hardness of all glass reinforced composites samples were found in the range of 85 to 100 in $\mathrm{R}$ scale at $23^{\circ} \mathrm{C}$ and $50 \%$ RH.

Scanning Electron Micrograph of glass reinforced composites based on phenolic resins were observed by ESEM EDAX XL-30Philips, Netherlands. Figures 2 (A, B, $\mathrm{C}, \mathrm{D} \& \mathrm{E})$ show the woven glass reinforced phenolic composites. It was found that the resin was distributed uniformly over the fabric, and the interfacial bonding between matrix and fiber was very good. Resin flow and impregnation of the glass fibers can be observed in the scanning electron micrographs. A clear phenolic oligomer adhesion is present in these micrographs and also glass fibers are observed to be embedded. Good matrix-fiber wetting was achieved and resin is also visible in between the glass fiber filaments.

Thermal stability of all phenolic oligomers based glass reinforced composites was carried by TGA on a Perkin Elmer thermo gravimetric analyzer at a heating rate of $10^{\circ} \mathrm{C} / \mathrm{min}$ in air atmosphere. In order to determine the thermal stability percentage (\%) weight loss at different temperature were calculated and the data of thermo gravimetric analysis are shown in Table 3 and Figure 3. The observation of thermo grams of all composites revealed following conclusion. In all composites about 4 to $15 \%$ weight loss was observed up to $200^{\circ} \mathrm{C}$ and about $20-32 \%$ weight loss was observe up to $300^{\circ} \mathrm{C}$ temp. After this temperature range slow weight loss was observed around $400^{\circ} \mathrm{C}$ temperature furthermore the thermo grams of all composites reveals that about $50 \%$ of weight loss occurred in the temperature range of $500^{\circ} \mathrm{C}$ temperature. Thermo gravimetric studies indicates the good interpenetration of thermosetting epoxy resin composites and these composite have very good thermal stability which proves suitability for high performance applications [23].

There are different methods for the determination of fiber content of glass reinforced composite. In acid dissolution method a specific dimension of composites is dissolve in strong $\mathrm{H}_{2} \mathrm{SO}_{4}$ and the results obtained is good agreement with the ratio of matrix: reinforcement. The results of chemical resistance (ASTM D 543) to various reagents are represented in Table 4. Examinationof these data indicated that each of the phenolic oligomers based glass reinforced composites were mostly stable in 1,4-dioxane, DMF and distilled water. However, very little loss in glass and negligible changes in weight and thickness were observed in standard sodium hydroxide solution. 
Table 1. Viscosity, Number average molecular Weight $(\overline{M n})$ and FT-IR characterization of Phenolic Oligomers.

\begin{tabular}{llll}
\hline $\begin{array}{l}\text { Phenolic } \\
\text { Oligomers }\end{array}$ & Viscosity $\mathbf{( c P )}$ & $\overline{\mathbf{M n}}$ & Wave Number $\left(\mathbf{c m}^{-1}\right)$ \\
\hline NPC & 950.31 & 5050 & $\begin{array}{l}1597.98,1512.92,1499.93 \text { (Aromatic C-C in plane vibration), 3413.94 (-OH stretching), 1230.89 (Aryl-Alkyl } \\
\text { vibration), 831.57, 754.38, 651.61 (Aromatic ring substitution at o, p position of phenyl ring) }\end{array}$ \\
NBC & 983.33 & 5065 & $\begin{array}{l}1511.38,1693.79,(\text { Aromatic C-C in plane vibration), 3429.98 (-OH stretching), 828.93, 730.42, 700.37 (Aromatic } \\
\text { ring substitution at o, p position of phenyl ring) }\end{array}$ \\
RPC & 1042.10 & 5458 & $\begin{array}{l}1670.32,1594.35,1500.54,1474.18 \text { (Aromatic C-C in plane vibration), 3391.83 (-OH stretching), 828.93, 830.76, } \\
813.63,755.45,693.15 \text { (Aromatic ring substitution at o, p position of phenyl ring) }\end{array}$ \\
RBC & 1100.00 & 5980 & $\begin{array}{l}1612.56,1598.42,1510.57,1446.04 \text { (Aromatic C-C in plane vibration), 3392.97 (-OH stretching), 829.24, 757.81, } \\
733.07,699.47 \text { (Aromatic ring substitution at o, p position of phenyl ring) }\end{array}$ \\
RCF & 1050.25 & 5600 & $\begin{array}{l}1617.81,1500.77,1459.47 \text { (Aromatic C-C in plane vibration), 3411.26 (-OH stretching), 1243.71 (Aryl-Alkyl } \\
\text { vibration), 816.57, 753.89, 1722.07, 692.51 (Aromatic ring substitution at o, p position of phenyl ring) }\end{array}$ \\
\hline
\end{tabular}

Table 2. Mechanical Properties of Phenolic oligomer based glass reinforced Composites.

\begin{tabular}{llllll}
\hline Sr. No. & Composites Resin System & Impact Strength (J/cm.) & Flexural Strength $\mathbf{( K g . ~}$ F/cm $\mathbf{c}^{2}$ & Rockwell Hardness $(\mathbf{R}$ Scale) & \% Fiber Content \\
\hline 1. & NPC & 1.55 & 437.00 & 95 & 37.81 \\
2. & NBC & 2.37 & 659.21 & 90 & 34.75 \\
3. & RPC & 2.85 & 876.56 & 95 & 37.44 \\
4. & RBC & 2.80 & 750.22 & 85 & 38.44 \\
5. & RCF & 2.95 & 675.02 & 80 & 36.21 \\
\hline
\end{tabular}

Table 3. Thermo gravimetric analysis (TGA) of Phenolic oligomer based glass reinforced Composite.

\begin{tabular}{|c|c|c|c|c|c|c|c|c|c|c|c|c|}
\hline \multirow{2}{*}{ Temp. ${ }^{\circ} \mathrm{C}$} & \multicolumn{12}{|c|}{$\%$ Weight Loss at different temperature $\left({ }^{\circ} \mathrm{C}\right)$} \\
\hline & 50 & 100 & 150 & 200 & 250 & 300 & 350 & 400 & 450 & 500 & 550 & 600 \\
\hline NPC & 0.6 & 1.7 & 2.4 & 4.7 & 9.4 & 20.0 & 28.84 & 30.98 & 42.88 & 50.05 & 56.50 & 60.48 \\
\hline NBC & 0.4 & 1.8 & 6.6 & 5.4 & 8.6 & 18.5 & 44.63 & 50.00 & 51.5 & 53.74 & 55.92 & 58.27 \\
\hline RPC & 1.9 & 4.6 & 9.9 & 15.1 & 21.5 & 31.9 & 45.22 & 48.85 & 53.92 & 54.16 & 57.69 & 61.31 \\
\hline RBC & 1.8 & 2.9 & 5.1 & 8.2 & 13.9 & 20.8 & 25.00 & 41.91 & 53.68 & 56.62 & 57.03 & 58.50 \\
\hline RCF & 0.8 & 4.8 & 7.8 & 10.5 & 12.5 & 21.5 & 25.0 & 41.91 & 53.68 & 56.62 & 58.03 & 58.50 \\
\hline
\end{tabular}

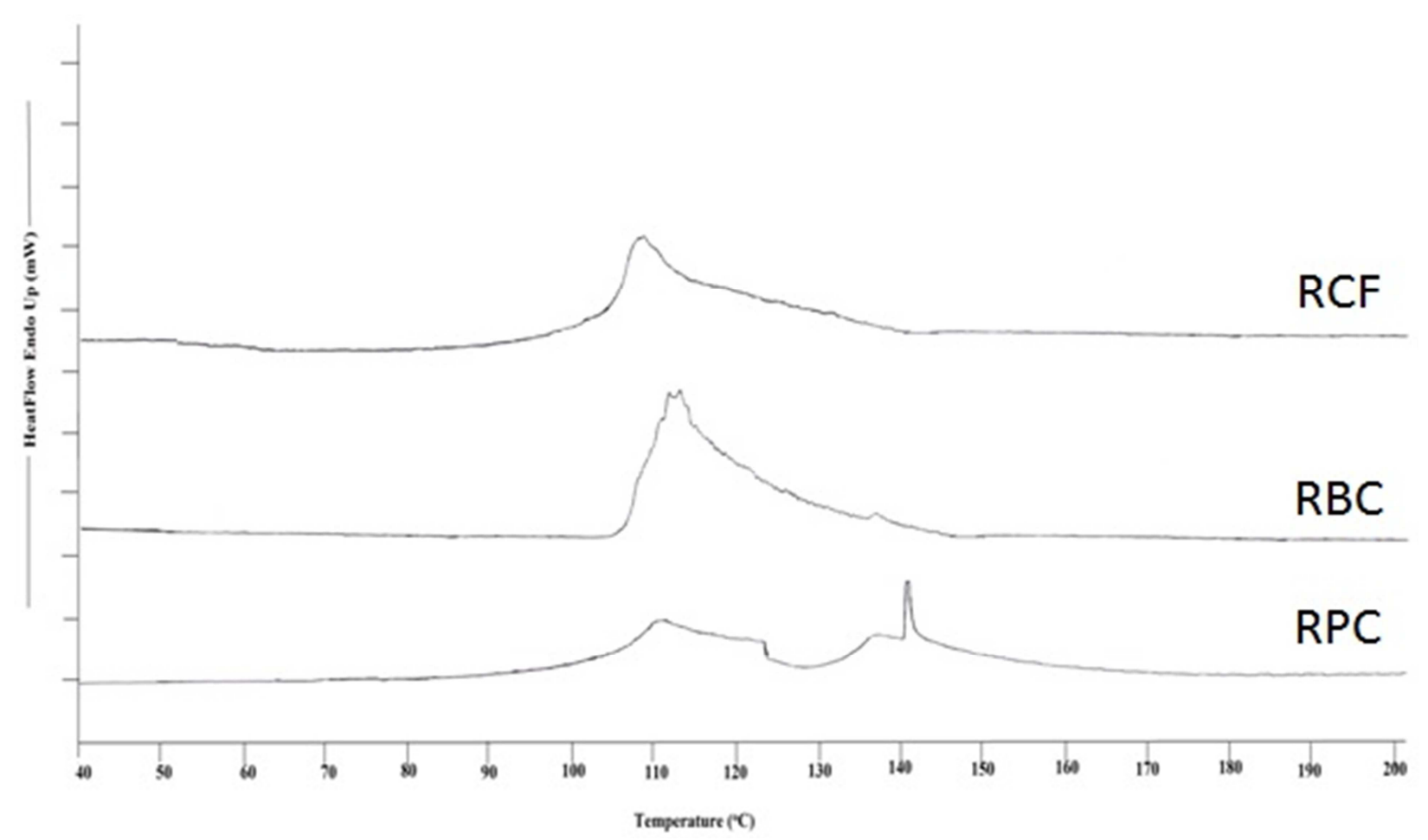

Figure 1. The Differential Scanning Calorimetry (DSC) thermo gram for phenolic oligomers. 


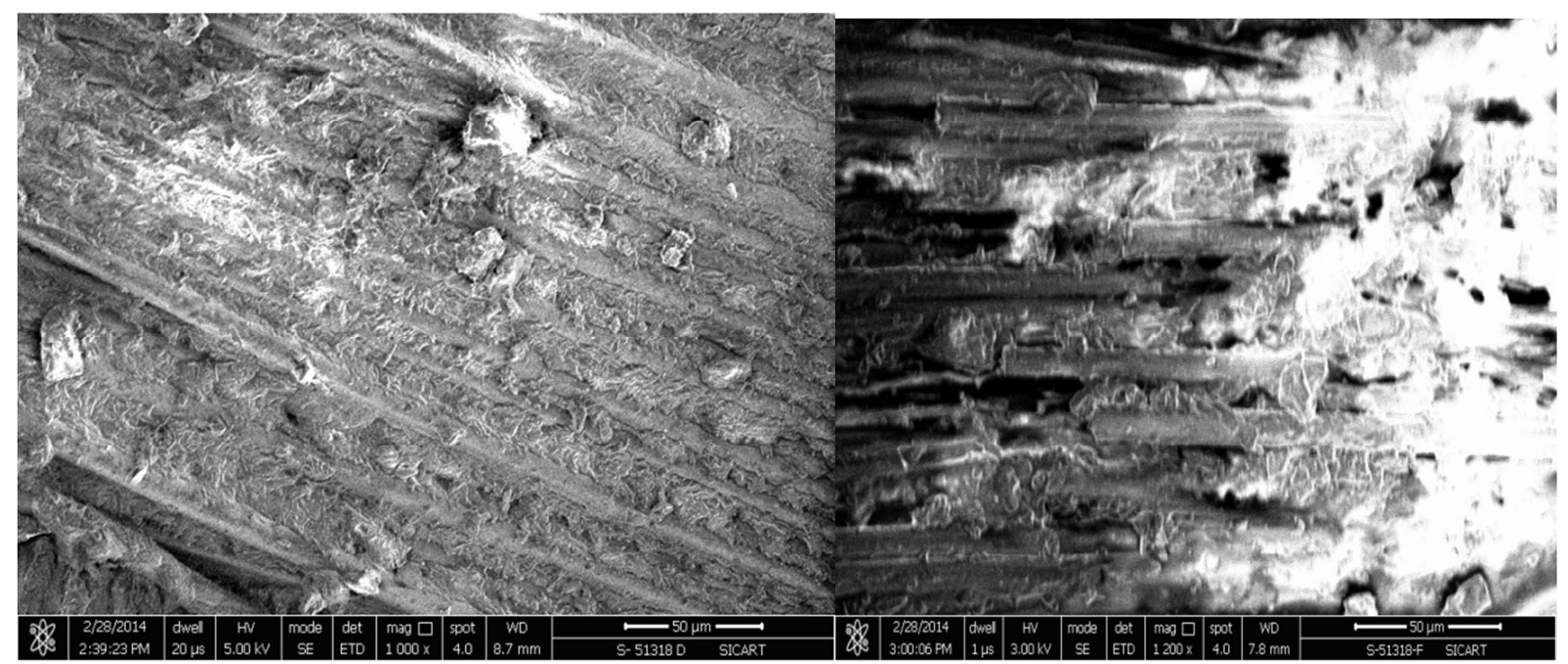

$\mathrm{A}-\mathrm{NPCB}-\mathrm{NBC}$

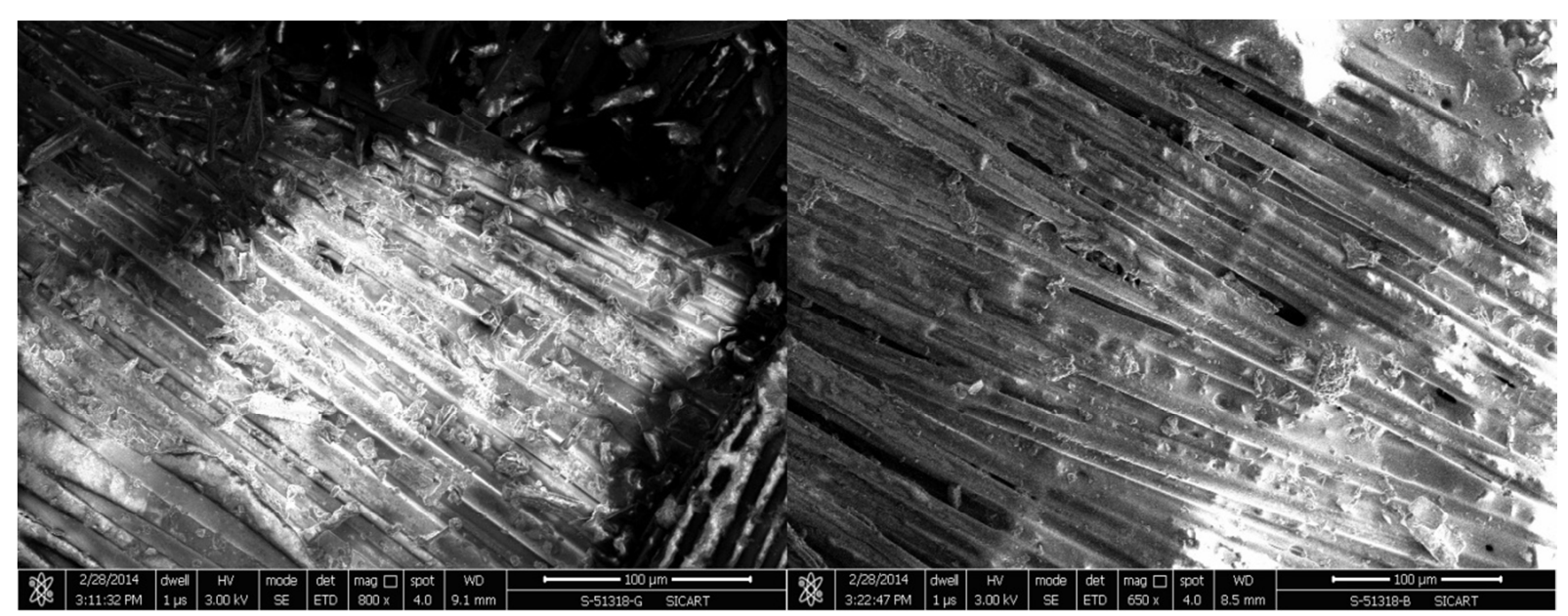

$\mathrm{C}-\mathrm{RPCD}-\mathrm{RBC}$

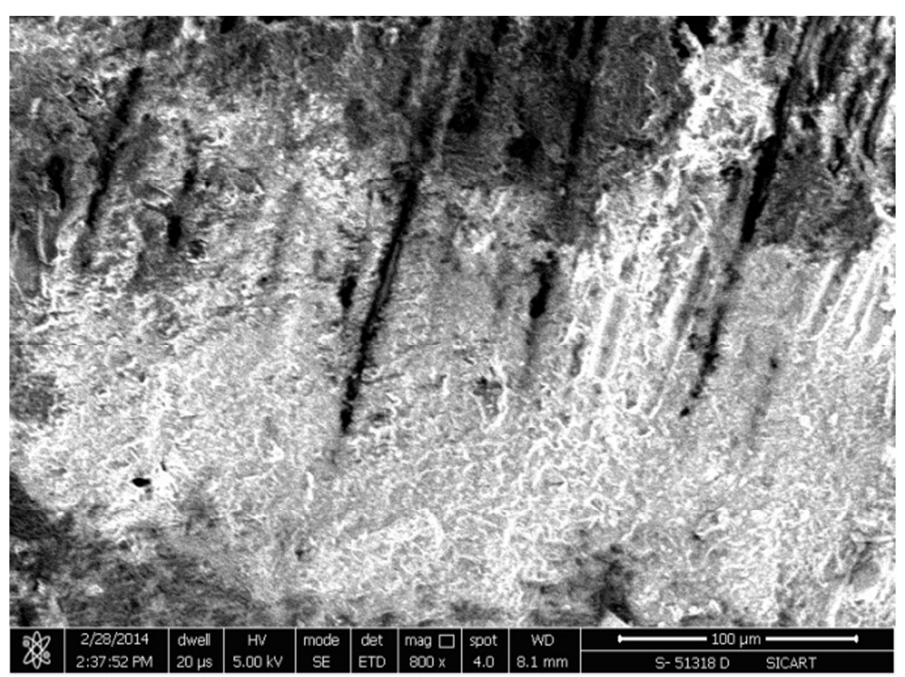

$\mathrm{E}-\mathrm{RCF}$

Figure 2. SEM micrograph of Phenolic oligomer based glass reinforced Composite. 


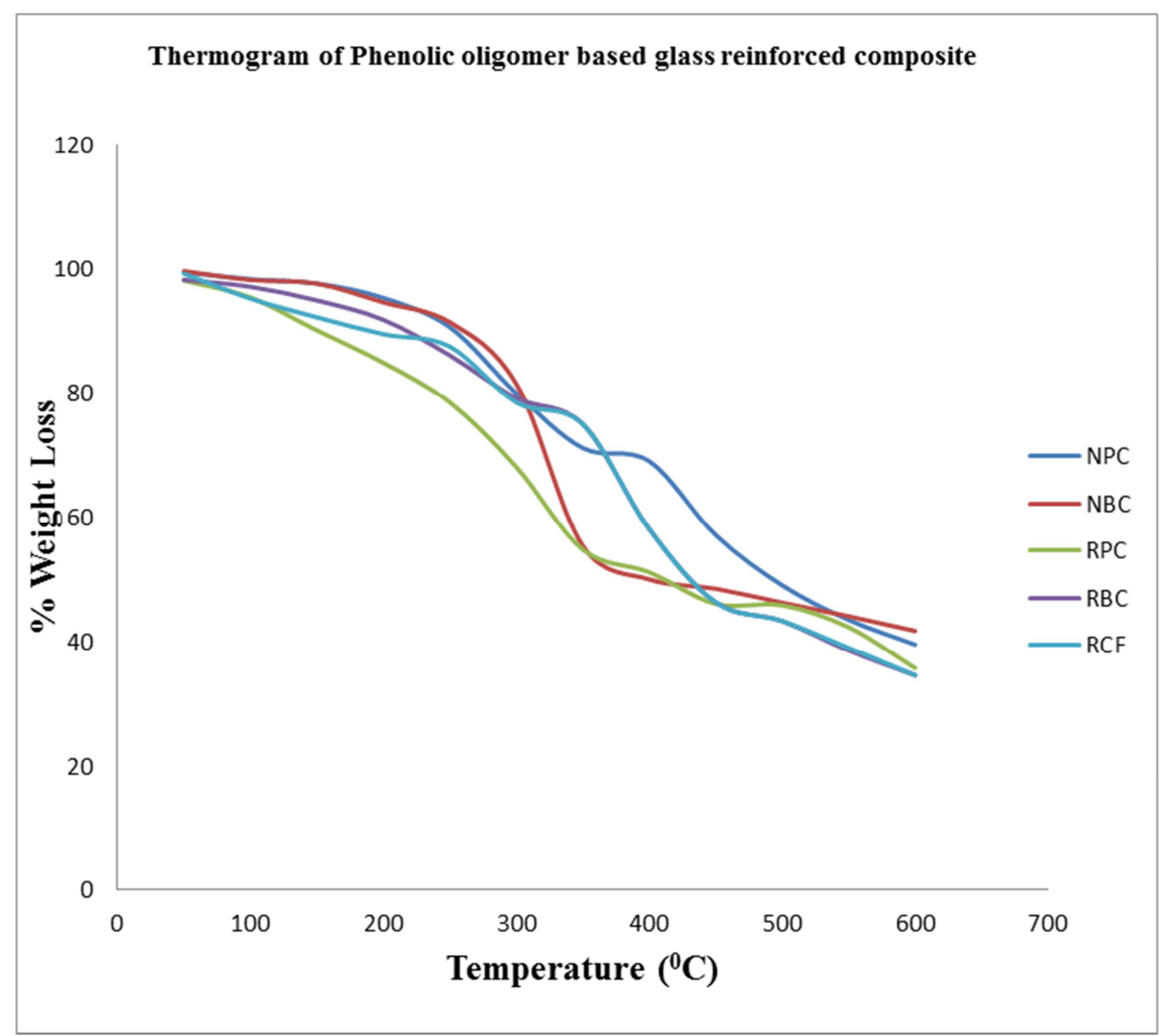

Figure 3. Thermo gravimetric analysis (TGA) of Phenolic oligomer based glass reinforcedcomposite.

Table 4. Chemical resistance of Phenolic oligomers based glass reinforced composite to standard chemical reagents.

\begin{tabular}{|c|c|c|c|c|c|c|c|c|c|c|c|}
\hline \multirow[b]{2}{*}{$\begin{array}{l}\text { Sr. } \\
\text { No. }\end{array}$} & \multirow{2}{*}{$\begin{array}{l}\text { Composites } \\
\text { Resin } \\
\text { System }\end{array}$} & \multicolumn{2}{|c|}{$10 \%$ NaOH Solution } & \multicolumn{2}{|c|}{$10 \% \mathrm{H}_{2} \mathrm{SO}_{4}$ Solution } & \multicolumn{2}{|l|}{ 1,4 Dioxane } & \multicolumn{2}{|l|}{ DMF } & \multicolumn{2}{|l|}{ Water } \\
\hline & & $\begin{array}{l}\% \text { Change } \\
\text { in Weight }\end{array}$ & $\begin{array}{l}\% \text { Change } \\
\text { in thickness }\end{array}$ & $\begin{array}{l}\text { \% Change } \\
\text { in Weight }\end{array}$ & $\begin{array}{l}\text { \% Change } \\
\text { in thickness }\end{array}$ & $\begin{array}{l}\text { \% Change } \\
\text { in Weight }\end{array}$ & $\begin{array}{l}\text { \% Change } \\
\text { in thickness }\end{array}$ & $\begin{array}{l}\text { \% Change } \\
\text { in Weight }\end{array}$ & $\begin{array}{l}\% \text { Change } \\
\text { in thickness }\end{array}$ & $\begin{array}{l}\text { \% Change } \\
\text { in Weight }\end{array}$ & $\begin{array}{l}\text { \%Change } \\
\text { in thickness }\end{array}$ \\
\hline 1. & NPC & 1.74 & 0.98 & 0.80 & 0.58 & $\mathrm{NC}$ & $\mathrm{NC}$ & $\mathrm{NC}$ & $\mathrm{NC}$ & $\mathrm{NC}$ & $\mathrm{NC}$ \\
\hline 2. & $\mathrm{NBC}$ & 1.79 & 0.82 & 0.84 & 0.60 & $\mathrm{NC}$ & $\mathrm{NC}$ & $\mathrm{NC}$ & $\mathrm{NC}$ & $\mathrm{NC}$ & $\mathrm{NC}$ \\
\hline 3. & RPC & 1.72 & 0.65 & 0.82 & 0.60 & $\mathrm{NC}$ & $\mathrm{NC}$ & $\mathrm{NC}$ & $\mathrm{NC}$ & $\mathrm{NC}$ & $\mathrm{NC}$ \\
\hline 4. & $\mathrm{RBC}$ & 1.75 & 0.83 & 0.78 & 0.65 & $\mathrm{NC}$ & $\mathrm{NC}$ & $\mathrm{NC}$ & $\mathrm{NC}$ & $\mathrm{NC}$ & $\mathrm{NC}$ \\
\hline 5. & $\mathrm{RCF}$ & 1.80 & 0.92 & 0.82 & 0.85 & $\mathrm{NC}$ & $\mathrm{NC}$ & $\mathrm{NC}$ & $\mathrm{NC}$ & $\mathrm{NC}$ & $\mathrm{NC}$ \\
\hline
\end{tabular}

\section{Conclusion}

Synergistic effects observed in mechanical properties exhibited by all phenolic oligomer based glass reinforced composites confirmed that good cross linking of reinforced and matrix material. The composites exhibited higher flexural, impact strength, chemical resistance due to good dispersion of resin in to fibre glass which also confirmed by scanning electron microscopy. Thus, phenolic oligomer reinforced with glass fibers can be utilized commercially as an excellent polymer matrix for engineering applications.

\section{Acknowledgement}

Authors are thankful to Director, Institute of Science \& Technology for Advanced Studies \& Research (ISTAR) and Director, Sophisticated Instrumentation Centre for Applied Research and Testing (SICART) for providing us research and analysis facility.

\section{References}

[1] A. J. Kinloch and A. C. Taylor, J. Mater. Sci, 38, 65-79 (2003).

[2] Y. Zhang, Q. Cai, Z. Jiang and K. Gong, J. App]. Polym. Sci, 92, 20382044 (2004).

[3] G. Z. Li, M. L. Ye and L. H. Shi, J. Appl. Polym. Sci, 60, 1163-68 (1996).

[4] Z. Fang, Z. Guo and L. Zha, Macromol. Mater. Eng, 289, 743748 (2004).

[5] E. J. Robinette, S. Ziaee and G. R. Palmese, Polymer, 45, 6143-6154 (2004).

[6] Ranade, S. L. Wunder and G. R. Baran, Polymer, 47, 43184327 (2006).

[7] L. Boogh, B. Pettersson, and J. A. E Manson, Polymer, 40, 2249-2261, (1999) 
[8] B. Francis, S. Thomas, J. Jose, R. Ramaswamy and V. L. Rao, Polymer, 46, 12372-12385(2005).

[9] C. P. Reghunadhan Nair, Prog. Polym. Sci, 29, 401-498 (2004).

[10] S. K. De, A. K. Bhowmick editors. Thermoplastic elastomers from rubberplastie blends, New York, NY: E1lisHonvoood (1990).

[11] R. R. Tatara, M. A. Rosentrater and Suraparaju, Industrial Crops and Products, 29(1), 9-15 (2009).

[12] J. A. Bryds0n, Plastics Materials, $5^{\text {th }}$ ed., Butenvorths (1989).

[13] R. N. Patel, S. Bandyopadhyay and A. Ganesh, A- Bioresour Technol., 97, 847, (2006).

[14] S. E. Mazzetto, D. Lomonaco,G. Mele, J. quimicanova., 32, 732, (2009).

[15] S. P. kumar, A. kumar, S. N. kumar, C. Kaushik, J. mater Sci., 44, 5894-5899, (2009).

[16] Aggarwal J. S., Menon M. C., Murthy B. G. K. and Zaheer S. H., Paint Mfr., 31, 47-53, (1961).
[17] Kashani M. A., Tyman J. H. and Wilczynski P., J. Am. Oil Chem. SOC., 55, 663-670, (1978).

[18] Annual book of ASTM standards, (2012).

[19] Zhang, Y. C., Ikeda, A., Hori, N., Takemura, A., Ono, H., Yamada, T., Characterization of liquefied product from cellulose with phenol in the presence of sulfuric acid, Bioresource technology, 97, 313-221. (2006).

[20] Pan, H., Shupe, T. F., Hse, C. Y., Characterization of liquefied wood residues from different liquefaction conditions, Journal of Applied Polymer Science, 105, 3739-3746. (2007).

[21] Jackson D. Megiatto Jr., Cristina G. Silva, Derval S. Rosa and Elisabete Frolline, Polym. Degradation and Stability, 93, 6, 1 109-1 121(2008).

[22] Thachil E. T. and Unnikrishnan K. P., International Journal of Polymeric Materials, 55, (6), 385-391, (2006).

[23] Pérez, J. M., Fernández, A., Thermal stability and pyrolysis kinetics of ligninphenol-formaldehyde resins, Journal of applied polymer science, DOI 10.1002/app.34817, (2011). 